\title{
Recognizing the Interest of Forest Owners to Combine pÿNature Oriented and Economic Uses of Forests
}

\section{Pynnönen, Sari}

2018-12

Pynnönen , S , Paloniemi , R \& Hujala , T 2018 , ' Recognizing the Interest of Forest Owners pÿto Combine Nature Oriented and Economic Uses of Forests ' , Small-Scale Forestry , vol. 17 , no. 4 , pp. 443-470 . https://doi.org/10.1007/s11842-018-9397-2

http://hdl.handle.net/10138/299999

https://doi.org/10.1007/s11842-018-9397-2

acceptedVersion

Downloaded from Helda, University of Helsinki institutional repository.

This is an electronic reprint of the original article.

This reprint may differ from the original in pagination and typographic detail.

Please cite the original version. 


\title{
Recognizing the interest of forest owners to combine nature-oriented and economic uses of forests
}

Pynnönen, Sari ${ }^{1 *}$; Paloniemi, Riikka²; Hujala, Teppo ${ }^{3,4}$

$1 *$ University of Helsinki, Faculty of Agriculture and Forestry, Department of Forest Sciences, P.O.Box 27, 00014 Helsingin yliopisto

sari.pynnonen@helsinki.fi

ORCID: 0000-0001-5427-8209

${ }^{2}$ Finnish Environment Institute (SYKE), Environmental Policy Center, P.O. Box 140; FIN-00251 Helsinki, Finland ORCID: 0000-0003-2853-535X

${ }^{3}$ University of Eastern Finland, School of Forest Sciences, P.O. Box 111, FI-80101 Joensuu, Finland

${ }^{4}$ Natural Resources Institute Finland (Luke), Latokartanonkaari 9, FI-00790 Helsinki, Finland

ORCID: 0000-0002-7905-7602

\begin{abstract}
Protecting biodiversity within separate set-aside conservation areas has not been effective enough to halt its loss. Thus, new approaches to conserve biodiversity alongside production are needed. The non-market values of a forest may play an essential role when the forest owner decides the use of their land. However, so far the service offerings other than related to timber production, have been scant. The mismatch between decision support services offered and the service interests of forest owners may result in the objectives of forest owners remaining unfulfilled. The aims of this study were to explore the links between family forest owners' forest management preferences and their objectives for the forest and secondly their preferences for decision support services.

Data were collected in a postal survey in the Northern Karelia region, Finland in spring 2014. Data consist of 298 survey answers that were analysed using multi-variate analyses. Two typologies were combined: clustering of forest ownership objectives and the preferred forest management style.

We found that the forest owner's objectives were demonstrated by their preferred way of managing the forest. Opinions about different decision aid services varied between cluster groups. The groups emphasizing nature values considered biodiversity related information about their forest more necessary than other groups. They were also less satisfied with the usability of the forest management plan. Forest advisory services should better acknowledge the prevalence of multiple objectives also among forest owners who are interested in timber selling. Developing services for forest owners with diverse socio-economic backgrounds, information needs and objectives is important.
\end{abstract}

\section{Keywords}

Family forest owners; Finland; Landowner survey; Multi-objective forest planning; Advisory services 


\section{INTRODUCTION}

There are several interlinked but contradictory megatrends going on in the use of forests. On one hand, there is a strong urge to move to a bio-based economy, where mainly renewable raw materials are used. This development is partly driven by the need to diminish carbon dioxide emissions to mitigate climate change and its societal impacts. On the other hand, there is a need to intensify efforts to conserve biodiversity and to strengthen the spatial connectivity between biotopes. Connectivity maintains the capability of habitats to reproduce and recover from disturbances (Rudnick et al. 2012), and improves the provision of multiple ecosystem services essential for human well-being.

Protecting biodiversity within separate set-aside conservation areas (Margules and Pressey 2000) has not been effective enough to halt its loss (Jenkins and Joppa 2009; Tittensor et al. 2014). Thus, new, more cost-effective, socially more agreeable and large-scale approaches to conserve biodiversity alongside production are needed. One promising opportunity is conserving biodiversity in managed areas, such as in production forests (Millennium Ecosystem Assessment 2005). Land owned by private individuals is of increasing interest for supplying non-timber services such as habitats for endangered species, and carbon sequestration (Kline et al. 2000; Markowski-Lindsay et al. 2016). Combining production and protection in the same areas, such as close-to-nature management approaches, advances ecological sustainability of forestry (Graham and Jain 1998; Hartley 2002) by increasing, for example, the structural diversity of the forest while maintaining timber production (Gamborg and Larsen 2003). These approaches include, for example, leaving more retention trees in harvesting, favouring light selection felling, and minimizing the removal of dead wood (Bieling 2004).

Some $86 \%$ of the land area in Finland is productive forest land, with 53\% owned by family forest owners (FFO). Altogether, there are about 630,000 FFOs in Finland. The share of the total timber volume in FFO owned productive forests is $71 \%$ (Finnish Forest Research Institute 2014). The high share of family-owned production forests means that the ecological status of these areas determines largely the level of biodiversity conservation in Finland. The 1996 Forest Act (1093/1996; amendments 1085/2013) has mandated maintaining biodiversity as one of the main objectives of forest management; nevertheless, certain forest habitats, such as grass-herb forests have become too scarce or altered to maintain biodiversity (Auvinen et al. 2007). Over one-third of Finland's endangered species live in forests (Rassi et al. 2010).

The common forest owner change patterns, such as urbanizing lifestyles, and increase of female owners are found to decrease the level of harvesting and increase the share of land set-aside for conservation (Côté et al. 2016). More FFOs are increasingly interested in forest benefits other than timber production, such as recreational and aesthetic forest values (Häyrinen et al. 2015; Leppänen 2010). In particular, female forest owners tend to consider aesthetics and conservation more important than male owners (Lidestav and Ekström 2000; Palander et al. 2009; Häyrinen et al. 2015). The nonmarket values of a forest may play an essential role when the FFO decides the use of their land (Amacher et al. 2002; Conway et al. 2003). FFOs with strong recreational objectives for their forests harvest less timber (Favada et al. 2009). An increasing diversity of objectives and motives for owning forests has been identified in numerous survey-based studies creating typologies and classifications of forest owners (e.g. Silver et al. 2015; Ficko et al. 2017). The general message from different studies is that a notable share of FFOs want their forests to provide several benefits.

However, services provided by forestry organizations have traditionally been driven by round wood market needs and the optimization of industry raw-material flows, emphasizing even-aged management of forest for maximal timber harvest (Mattila et al. 2013). Mattila and Roos (2014) found in their study about Finnish and Swedish forest sector actors that because of that rather one-sided supply of services that disregards the diversity of FFO objectives, service providers have difficulty in reaching those FFOs who are oriented to targets other than industrial timber production. Hence those FFOs are left outside the current service market.

Meeting the growing timber demand would require also reaching these non-timber-production oriented FFOs (Palander et al. 2009; Korhonen et al. 2012), but so far the service offerings related to non-timber products, nature- and gameoriented forest management, or landscape and recreational values of forests have been scant, superficial or unsuccessful. The possible disinterest towards solely timber-production oriented services that do not meet one's objectives or values challenges the availability of wood needed in the shift to a bio-economy (Haltia et al. 2017; Päivinen et al. 2017), and also jeopardize the opportunities to actively produce multiple ecosystem services from forests. 
Forest management planning and the advisory services supporting the implementation of a plan have been the central tools of forest policy to provide support for FFO decision-making and hence facilitate even timber flows for the industry. About $45 \%$ of forest estates in Finland have a forest management plan (FMP) (Hänninen et al. 2011). In earlier studies, having a valid holding-level FMP has been connected to conducting harvests (Ní Dhubháin et al. 2010; Hänninen et al. 2011) and pursuing management activities (Ovaskainen et al. 2017). To ensure the provision of multiple ecosystem services in forested landscapes, the way the forest planning is conducted and how owner motivations are taken into account, matters.

Decision-making about forests can be supported by various information means and services. Understanding FFO attitudes and behaviour helps to influence their actions via policy instruments (Butler et al. 2016), and hence to ensure the best possible outcome for society from the use of forests. As the strong emphasis on supporting timber production is no longer effective for some owner groups (Häyrinen et al. 2015), adjusting different policy programmes to match the multiple objectives of FFOs may motivate them towards joint production of timber and non-timber services. This results in more efficient forest policy (Kline et al. 2000).

The Finnish model of forest planning relies on finding out the overall objectives of a forest owner and then adjusting the management to achieve them. However, articulating the overall objectives of owning forest land in a numerical form that could be operationalized as forest treatments for planning calculations has been considered difficult for most FFOs. Forest management planning in Finland still mostly concentrates on operations aiming to maximize constant timber harvest or economic gain, and hence it best serves those forest owners who are interested in forestry (Hokajärvi et al. 2009; Mattila and Roos 2014). In practical advisory and forest management planning situations, forest owner objectives related to nature values have not been mapped much (Kumela et al. 2013).

According to studies (e.g. Hujala et al. 2007; Kurttila et al. 2010), FFOs nevertheless do want their FMPs and relevant advisory services to take their own objectives and wishes into account. Forest owner attitudes towards forests and their uses, as well as their objectives, play an important role in forest management decisions (Karppinen 2012; Silver et al. 2015). A meta-analysis of forest owner typologies found that the intensity of how land owners manage their forests is associated with their objectives (Blanco et al. 2015). Hence, illustrating planning alternatives via practical forest management operations could be an easier way to picture decisions and their consequences and hence facilitate the decision making of a FFO. We argue that instead of trying to establish overall objectives about forest ownership preferences and then adjusting the forest management operations to fulfil these, the professionals may first elicit from forest owners the practical way they wish to manage their forests, which can then be more easily interpreted as forest use objectives and used in planning calculations.

Efforts to increase wood mobilization may intensify competition between different land uses. In this situation, there is a need to develop services that recognize intangible forest values like nature conservation and aesthetics (Häyrinen et al. 2015; Mattila and Roos 2014). Providing ecosystem services other than timber may be the forest owner's main objective or part of multi-objectivities. However, although the need to develop new services is evident, there has been little research on FFO opinions of the actual services offered (Staal Wästerlund and Kronholm 2016). Also the research to systematically develop the means to identify, concretize and convert forest owner objectives into practical changes in forest management is still lacking (Silver et al. 2015). In this light, paying attention to the different objectives of forest owners and the availability of services that support their realization is very topical.

This paper explores the links between FFO forest management preferences, ownership objectives, and services in the frame of increasing diversification of forest management approaches. The research questions are:

1) How are objectives and forest management preferences of Finnish FFOs connected to and overlapping with each other?

2) How are the objectives and management preferences linked to current advisory services?

3) How should the forest advisory services be developed to better match FFO needs?

The aim of this study is two-fold. Firstly, we test the hypothesis that asking FFOs about their preferred forest management style or approach instead of their objectives gives the same information more versatile for directing decision support services. Secondly, we scrutinize FFO preferences for decision support services to identify patterns that may indicate 
their willingness to engage in nature management activities in their forests, which informs developing related services for everyday forestry practice.

We begin by describing the data collection and the characteristics of respondents as well as the statistical analyses conducted. The results are presented and discussed in following sections. We conclude with recommendations for the development of forest management planning and advisory services.

\section{MATERIAL AND METHODS}

\section{Data collection}

Data were collected in a postal survey in the Northern Karelia region of Finland (Fig. 1) in the spring of 2014 as part of a larger survey also targeted to other regions in Finland (Paloniemi et al. 2017). Northern Karelia was chosen as the target region for this study because it has both an active forestry sector with high felling rates and has been forward-looking in enhancing forest biodiversity (Suomen Metsäkeskus 2016).

The sampling consisted of two parts. Subsample 1 consisted of all FFOs in the target region who have established a private forest conservation area (PFCA) contract within the government-funded, voluntary Forest Biodiversity Programme (METSO) (Government of Finland 2014) or who have a forest environmental management contract (EMC) signed between 2004 and 2013. These private conservation areas are set-aside areas where no commercial felling is allowed. Subsample 2 was a representative sample of all FFOs in Northern Karelia, excluding forest holdings smaller than 2 hectares and those in Subsample 1. The first mailing was followed by a reminder letter and a new questionnaire about two weeks after the first mailing.

Subsample 2 was generated with systematic sampling in which the holdings in the target population were arranged from smallest to largest by forest area and alphabetically within each holding size class. Weighting of the classes was done based on the Forest Statistical Bulletin by Leppänen and Sevola (2014). The sampling interval was determined so that the targeted sample would be as proportional to the Subsample 1 as possible within the budget resources, yielding 420 forest holdings in the Subsample 2. All sample sizes and numbers of responses are listed in Table 1.

Table 1: Description of the sampling method and response rates

\begin{tabular}{|c|c|c|c|c|c|}
\hline Sample & Type of sample & $\begin{array}{l}\text { Target } \\
\text { population }\end{array}$ & $\begin{array}{l}\text { Number of } \\
\text { questionnaires } \\
\text { sent }\end{array}$ & $\begin{array}{l}\text { Number of } \\
\text { questionnaires } \\
\text { received }\end{array}$ & $\begin{array}{l}\text { Response } \\
\text { rate }(\%)\end{array}$ \\
\hline $\begin{array}{l}\text { Subsample } \\
1\end{array}$ & $\begin{array}{l}\text { All forest owners who have a } \\
\text { private forest conservation area } \\
\text { (PFCA) contract AND } \\
\text { all forest owners who have a } \\
\text { forest environmental } \\
\text { management contract (EMC) } \\
\text { signed in 2004-2013. }\end{array}$ & 599 & $\begin{array}{l}\text { PFCA } 267 \\
\text { EMC } 332 \\
\text { subtotal } 599\end{array}$ & $\begin{array}{l}86 \\
109 \\
\text { subtotal } 195\end{array}$ & 32.6 \\
\hline $\begin{array}{l}\text { Subsample } \\
2\end{array}$ & $\begin{array}{l}\text { Systematic sampling in the } \\
\text { Northern Karelia region, } \\
\text { excluding forest holdings } \\
\text { smaller than } 2 \text { hectares and } \\
\text { those in Subsample } 1 .\end{array}$ & 19286 & 420 & 103 & 24.5 \\
\hline TOTAL & & 19885 & 1019 & 298 & 29.2 \\
\hline
\end{tabular}




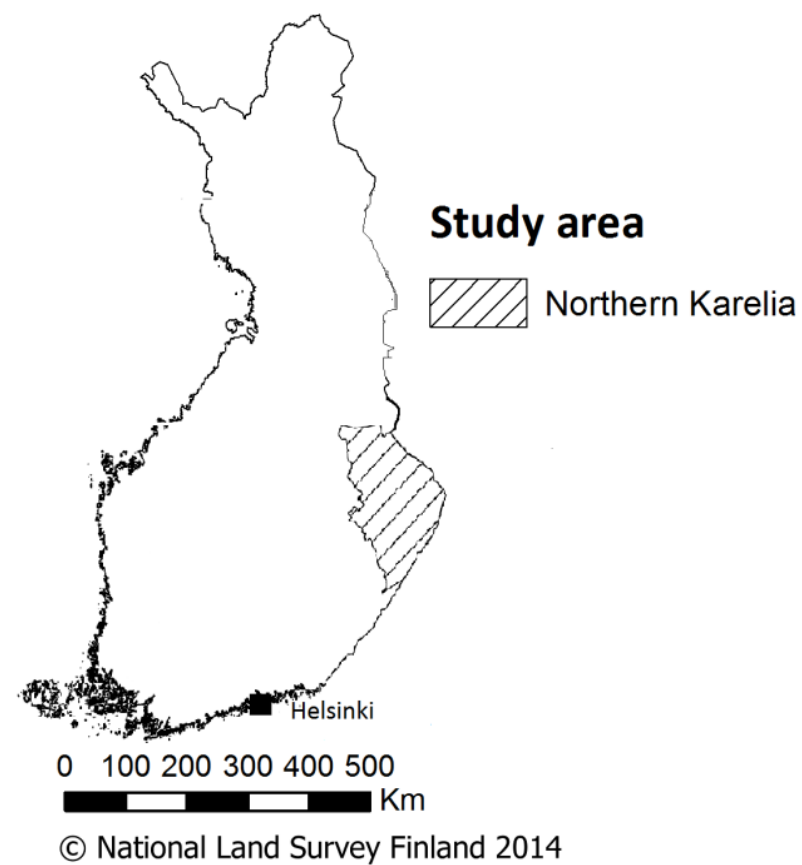

Fig 1. Map of survey area in Northern Karelia, Finland. Picture modified from Harlio (2017).

\section{Survey questions}

The survey questions about forest ownership objectives and information needs were formulated partly based on earlier research carried out in Finland (e.g. Paloniemi and Tikka 2008; Paloniemi and Vainio 2011; Primmer et al. 2014). One question was about the importance of forest ownership objectives and included ten statements. A five-point Likert scale from very important to not at all important was employed. Other question was about forest management style and included variables describing alternative forest management practices. Respondents were asked how likely it was that they would apply those in the next five years on a five-point scale.

We also asked how useful (very useful - not at all useful) the respondents found different services and information related to biodiversity conservation, for example, maps or photos or meetings with an expert. Finally, the level of agreement with statements about the FMP and related advisory services was questioned. The original survey questions are presented in Supplemental materials. The statement sets were tested with landowner representatives before the questionnaire was sent to landowners.

Demographic background information (including age, gender, education level, place of living and household income level) and key variables about the forest holding (including form of possession of the holding, duration of forest possession and annual income derived yearly from the forest) were also requested.

\section{Evaluation of non-response bias}

Non-response bias was evaluated for the wider survey, which consisted of three sample areas in addition to Northern Karelia (Paloniemi et al. 2017). We compared the basic characteristics of the respondents with the Finnish Forest Owner Survey 2010 results (Hänninen et al. 2011) and conducted 74 non-response telephone interviews. The telephone interviews were conducted to find out reasons for not responding and whether those would be associated with nonrespondents' background characteristics.

For the telephone interviews, 150 survey receivers were picked from the non-respondents, weighting the shares in relation to the size of subsamples. Telephone numbers were found for 117 persons, of which 74 answered to first or second call and agreed to a phone interview. Respondents were asked whether they remembered receiving the questionnaire and if 
yes, why they did not answer. Basic background information was gathered: year of birth, gender, occupation, and place of living (directly on the forest holding, in the same municipality or elsewhere). Some information about the forest property was also requested: how they own the forest (alone, with spouse, estate of heirs, joint administration of the property), how long they have had the holding, and the aggregate area of their forest holdings. They were also given a chance to comment on the survey or the theme. Interviews revealed that most common reasons for not answering were hurry and lapse of memory. No particular regularities were found in interviewees' background. Telephone interviews were conducted by one person during the daytime in June 2014.

\section{Description of respondents}

Representativeness of our data was assessed in comparison to the previous nationwide forest owner survey (Hänninen et al. 2011). The differences within the whole distributions were tested with Chi square -tests and if significant differences occurred, differences between individual shares were tested with z-tests. In our study $76 \%$ of respondents were male, which corresponds well with Hänninen et al. (2011) results (Table 2). In the present study, more respondents were born between 1940 and 1949 (35\% compared to 24\%) and fewer between 1960 and 1969 (14\% compared to 19\%), the former difference being significant.

Table 2: Description of socio-demographic background information of the survey respondents. Differences in the background of the respondents between this study (N=298) and the Finnish Forest Owner Survey 2010 (N=6318) were tested with $\mathrm{X}^{2}$-test and z-test. The test results are presented in Supplemental materials.

\begin{tabular}{|c|c|c|c|c|}
\hline & & Survey & $\begin{array}{l}\text { Finnish Forest Owner } \\
\text { Survey } 2010^{a}\end{array}$ & \\
\hline & & $\%$ of respondents & $\%$ of forest owners & $p$ \\
\hline Gender & & & & \\
\hline Female & & 24 & 25 & \\
\hline Male & & 76 & 75 & \\
\hline Occupation & & & & $0.000 * * * b$ \\
\hline Salaried perso & & 36 & 30 & \\
\hline Farmer & & 7 & 16 & \\
\hline Other self-em & oyed & 4 & 7 & \\
\hline Pensioner & & 51 & 45 & \\
\hline Other & & 2 & 2 & \\
\hline Place of resid & & & & \\
\hline Permanently o & the forest holding & 36 & 42 & \\
\hline $\begin{array}{l}\text { Elsewhere in } \mathrm{t} \\
\text { holding }\end{array}$ & e same municipality as the & 20 & 22 & \\
\hline $\begin{array}{l}\text { Outside the } \mathrm{m} \\
\text { located }\end{array}$ & hicipality where the holding is & 44 & 35 & $0.05^{*}$ \\
\hline Year of birth & (Age classes) & & & \\
\hline 1922-1939 & (75-92) & 12 & 14 & \\
\hline 1940-1949 & $(65-74)$ & 35 & 24 & $0.01 * *$ \\
\hline 1950-1959 & $(55-64)$ & 29 & 32 & \\
\hline 1960-1969 & $(45-54)$ & 14 & 19 & \\
\hline 1970-1979 & (35-44) & 8 & 11 & \\
\hline $1980-$ & (34 or younger) & 2 & - & \\
\hline Form of own & ship & & & \\
\hline Alone & & 55 & $76^{c}$ & \\
\hline Together with & pouse & 21 & & \\
\hline Joint administ & tion of property & 16 & 13 & \\
\hline Estate of heirs & & 8 & 12 & \\
\hline
\end{tabular}


${ }^{a}$ Hänninen et al. 2011

${ }^{b}$ The result of $\mathrm{X}^{2}$-test is reported, because the conditions for $\mathrm{z}$-test are not fulfilled.

${ }^{c}$ Hänninen et al. 2011 did not separate the owning alone or with the spouse but reported the categories together.

Among the survey respondents there were more pensioners $(51 \%)$ and salaried persons (36\%) than in the nationwide forest owner survey data - their respective shares were $45 \%$ and $30 \%$ - but these differences were not significant. The shares of farmers (7\%) and other self-employed (4\%) were smaller than in the control data (16\% and $7 \%)$ as can be seen in Table 2. For this comparison the $\mathrm{X}^{2}$-test indicated significant differences $(\mathrm{p}=0.000)$ but the conditions for calculating z-test are not fulfilled (less than 30 observations) for more accurate analysis.

A significantly higher share of present respondents live in a different municipality than where their forest is located (44\% versus 35\%). Hänninen et al. (2011) did not separate groups that own the forest alone or with their spouse. However, the combined sum of those groups (55\% and $21 \%$ respectively) in our survey data corresponds well with their results. The share of jointly administered properties is somewhat larger in our data (16\% compared with 13\%) and estate of heirs is somewhat smaller ( $8 \%$ compared with $12 \%)$.

Because the data were collected as part of a wider survey with questions about voluntary conservation measures, the sampling is biased towards those experienced in voluntary conservation. Those FFOs did not necessarily answer the questions about forest management since it may not concern them. Similarly, respondents in a random sample may have refrained from answering conservation themed questions. The use of the above subsamples ensures the acquisition of more varied knowledge from FFOs with differing forest ownership objectives.

\section{Grouping forest owners}

There are several approaches to the construction of forest owner groupings (see e.g. Emtage et al. 2007; Hujala et al. 2013). Combining several typologies with different viewpoints at the same time generated richer insights into forest owner motivations and behaviours (Hujala et al. 2013). We combined one grouping based on the ownership objectives of FFOs and the other grouping based on their forest management style. The aim of combining was to explore the relationship between objectives and preferred management decisions, and whether this could be used when creating tools to help decision-making.

To group the respondents this article applies factor and cluster analyses. These methods discover latent attitudes and courses of action of forest owners. The examined attributes were forest ownership objectives and forest management styles. Discovered cluster groups were then tested with sum variables about FFOs' preferred tools for information acquisition. This was done with one-way analysis of variance (ANOVA) to find differences in the means. Sum variables were formed for biodiversity conservation tools and forest management planning services. Demographic variables such as gender, age and educational background were tested using cross-tabulation analysis and Pearson's chi-squared $\left(\chi^{2}\right)$ tests. Missing data were handled with pairwise deletion in all analyses to minimize the loss of data. All analyses were conducted using IBM SPSS Statistics, Version 24.0.

\section{Factors}

Factor analysis is a multivariate method used to determine the number of distinct constructs assessed by a set of measures and to provide information about the number of common factors underlying them (Fabrigar and Wegener 2012). We used exploratory factor analysis; hence, there were no clear expectations about the underlying structure of correlations (Fabrigar and Wegener 2012). Although the communalities in the chosen solutions were consistently low, the number of factors was, however, small (only two in both cases) and there was mostly a rather high number of indicators per factor (five to six). Communalities can be interpreted as the proportion of the variance accounted for by the common factors (Fabrigar and Wegener 2012). With these prerequisites fulfilled, a good factor solution was achieved (MacCallum et al. 1999). Factor analysis with maximum likelihood and Kaiser-Varimax rotation was applied. 
Forest ownership objectives were studied using a set of ten variables (Table 3). All alternative solutions from one to four factors were tested and the two-factor solution, which best fulfilled the statistical preconditions, was chosen. The solution was improved by deleting two variables with low communalities, the final result including 8 out of 10 variables. The Kaiser-Meyer-Olkin test value for sampling adequacy (0.703) and Bartlett's test of sphericity $(p<0.001)$ indicate that factor analysis is appropriate for the data set (Metsämuuronen 2011 pp 671). Forest management style was studied using a set of 12 variables (Table 4). All alternative solutions from one to four factors were tested and solution with two factors was chosen with the same criteria as above. One variable was left out because of low communality (lower than 0.2); hence, the final solution comprised 11 variables. The Kaiser-Meyer-Olkin test for sampling adequacy (0.855) and Bartlett's test of sphericity $(p<0.001)$ gave again adequate values.

\section{Clusters}

Clustering is used to create forest owner groups within which the respondents are expected to display similar behaviour and decision-making, whereas displaying dissimilarities with individuals in other groups (Kaufman and Rousseeuw 1990). The factor scores were used to cluster the respondents with a k-means algorithm. The best solutions with three clusters was selected by testing all solutions from two to four clusters and then choosing the best based on a subjective estimation of their interpretability (Jain 2010). Groups were named based on final cluster centre information (Tables 5 and 6).

\section{Sum variables}

Sum variables concentrate the opinions of respondents from several statements into one variable. Three sum variables were formed based on means for receiving information about ecologically valuable spots in their forests and three sum variables were based on satisfaction with FMP and related advisory services. The internal consistency of sum variables was tested using Cronbach's alpha (Cronbach 1951). All constructs exceed 0.7, which is recommended as the minimum level of Cronbach's alpha to indicate internal consistency (Gruen et al. 2000).

\section{Cross-tabulation and comparison of means}

Both typologies were cross-tabulated with socio-economic background variables to rule out the possibility that observed differences between groups were due to the background of the respondents, as the background variables have explained differences in landowner objectives and harvesting behaviours or intentions in many studies (Butler et al. 2016). Pearson's chi-squared test was applied.

One-way ANOVA testing was used to compare the means of sum variables between ownership objective clusters and forest management style groups to analyse what kind of information tools are most preferred by various forest owner groups. Post-hoc-tests were carried out using Tukey HSD and Games-Howell tests.

\section{RESULTS}

\section{Forest ownership objectives and management style}

For forest ownership objectives, two factors were extracted (Table 3). They explained 51\% of the total variance. The first factor was characterized by ecosystem services other than timber production, especially availability of berries and mushrooms, and recreational values. It was named 'recreation and nature'. The factor explained $35.1 \%$ of the total variation. The second factor described economic values of forest, and was named 'timber production and economy'. It explained $16.0 \%$ of the total variation.

Table 3: Forest ownership objectives $\left(n=253^{\mathrm{a}}\right)$. Result of the factor analysis (maximum likelihood, varimax rotation applied). 


\begin{tabular}{llll}
\hline Variable & $\begin{array}{l}\text { Factor I: } \\
\text { Recreation } \\
\text { and nature }\end{array}$ & $\begin{array}{l}\text { Factor II: Timber } \\
\text { production and } \\
\text { economy }\end{array}$ & Communalities \\
\hline Berries and mushrooms & $\mathbf{0 . 6 9 3}$ & -0.033 & 0.482 \\
\hline Recreational values & $\mathbf{0 . 5 9 3}$ & -0.240 & 0.409 \\
\hline Securing the availability of clean water & $\mathbf{0 . 4 9 9}$ & -0.007 & 0.249 \\
\hline Securing or enhancing scenic values & $\mathbf{0 . 4 7 2}$ & -0.299 & 0.312 \\
\hline Carbon sequestration and maintaining carbon sinks & $\mathbf{0 . 4 2 4}$ & -0.189 & 0.215 \\
\hline Maintaining biodiversity & $\mathbf{0 . 4 0 9}$ & -0.246 & 0.228 \\
\hline Maximizing economic profit & -0.083 & $\mathbf{0 . 7 0 8}$ & 0.509 \\
\hline Timber production & -0.188 & $\mathbf{0 . 6 7 8}$ & 0.494 \\
\hline Eigenvalue & $\mathbf{2 . 8 0 5}$ & $\mathbf{1 . 2 8 1}$ & $\mathbf{1 6 . 0 1 3}$ \\
\hline \% of total variation explained (51.072) & $\mathbf{3 5 . 0 5 9}$ & & \\
\hline
\end{tabular}

${ }^{\mathrm{a}}$ The missing observations were excluded pair-wise in the analysis.

Two factors were also formed for forest management style (Table 4). They explained 53\% of the total variance. The first factor described willingness to shift towards multi-objective forest management practices and was named 'diversifying forest management practices'. The second factor was characterized by willingness to apply nature management practices and was named 'emphasis on nature'. The two factors explained 40.7 and $12.7 \%$ of the variation, respectively.

Table 4: Forest management style $\left(\mathrm{n}=248^{\mathrm{a}}\right)$. Result of the factor analysis (maximum likelihood with varimax rotation applied).

\begin{tabular}{|c|c|c|c|}
\hline & Factor I: & Factor II: & \\
\hline Variable & $\begin{array}{l}\text { Diversifying } \\
\text { forest } \\
\text { management } \\
\text { practices }\end{array}$ & $\begin{array}{l}\text { Emphasis on } \\
\text { nature }\end{array}$ & $\begin{array}{l}\text { Communali- } \\
\text { ties }\end{array}$ \\
\hline $\begin{array}{l}\text { I will obtain a forest management plan (FMP) focusing on } \\
\text { uneven-aged management }\end{array}$ & 0.709 & 0.393 & 0.657 \\
\hline $\begin{array}{l}\text { I will renew my FMP if there are new focuses available, even } \\
\text { it does not expire yet }\end{array}$ & 0.703 & 0.280 & 0.573 \\
\hline I will obtain a multi-objective FMP for my forests & 0.678 & 0.356 & 0.586 \\
\hline $\begin{array}{l}\text { I will obtain a harvesting plan that utilizes uneven-aged } \\
\text { harvesting methods (light selection felling or small-area clear } \\
\text { felling) }\end{array}$ & 0.621 & 0.118 & 0.400 \\
\hline $\begin{array}{l}\text { I apply both so-called traditional and alternative forest } \\
\text { management regimes }\end{array}$ & 0.457 & 0.036 & 0.210 \\
\hline $\begin{array}{l}\text { I will leave more retention trees in a felling area than is } \\
\text { required by minimum requirements of the PEFC Forest } \\
\text { certification }\end{array}$ & 0.229 & 0.750 & 0.615 \\
\hline I preserve selected areas of my forest holding & 0.106 & 0.61 & 0.383 \\
\hline $\begin{array}{l}\text { I will obtain an FMP focusing on nature management, } \\
\text { including i.a. surveying of nature values and } \\
\text { recommendations for their maintenance and enhancement }\end{array}$ & 0.520 & 0.561 & 0.585 \\
\hline $\begin{array}{l}\text { I will participate in an environmental restoration project or } \\
\text { start my own }\end{array}$ & 0.105 & 0.493 & 0.254 \\
\hline I manage my forests in a game-friendly manner & 0.143 & 0.464 & 0.236 \\
\hline $\begin{array}{l}\text { I only apply so-called alternative forest management regimes, } \\
\text { such as uneven-aged stands }\end{array}$ & 0.290 & 0.448 & 0.285 \\
\hline Eigenvalue & 4.478 & 1.394 & \\
\hline$\%$ of total variation explained $(53.376)$ & 40.707 & 12.669 & \\
\hline
\end{tabular}

${ }^{\mathrm{a}}$ The missing observations were excluded pair-wise in the analysis. 


\section{Forest ownership clusters based on created factors}

In the forest ownership objective clustering (Table 5), the biggest group was those emphasizing economic use of their forests. They had a rather strong negative loading for recreation and nature and a positive loading for timber production and economy. This group had a share of $44.7 \%$. A group having multiple objectives $(32.8 \%)$ valued both recreation and nature and timber production and economy. The smallest of the groups, $(22.5 \%)$, was those emphasizing nature values. They were characterized by opposing timber production and maximizing economic profit.

Table 5: Grouping based on ownership's objectives; k-means clustering $(n=253)$

\begin{tabular}{|c|c|c|c|c|c|}
\hline & $\begin{array}{c}\text { Emphasis on } \\
\text { economic use } \\
(n=113, \\
44.7 \%)\end{array}$ & $\begin{array}{c}\text { Multiple } \\
\text { objectives } \\
(\mathrm{n}=\mathbf{8 3}, \mathbf{3 2 . 8 \%})\end{array}$ & $\begin{array}{c}\text { Emphasis on } \\
\text { nature }(\mathrm{n}=57, \\
22.5 \%)\end{array}$ & $\mathbf{F}$ & Sig. \\
\hline Recreation and nature & -0.72601 & 0.70562 & 0.21689 & 193.971 & $<0.000$ \\
\hline $\begin{array}{l}\text { Timber production and } \\
\text { economy }\end{array}$ & 0.37658 & 0.29986 & -1.24346 & 256.545 & $<0.000$ \\
\hline
\end{tabular}

In the forest management style clustering, the biggest group was diversifying management practices (45.6\%) (Table 6). They found diversifying management practices important and had clearly stronger emphasis on nature values than the timber production group, although not as strong as the nature manager group. Clearly fewer respondents (35.5\%) were in a group that only aimed at timber production, having neither the intention to diversify their management nor to place any additional effort on nature friendliness. The smallest group was again those who aimed to manage their forests to actively add nature value there. Their share was $19 \%$.

Both clusterings formed similar groups despite one of them being based on ownership objectives and another based on forest management style.

Table 6: Grouping based on forest management style, k-means clustering $(n=248)$

\begin{tabular}{|c|c|c|c|c|c|}
\hline & $\begin{array}{c}\text { Diversifying } \\
\text { management } \\
\text { practices } \\
(n=113, \\
\mathbf{4 5 . 6 \%})\end{array}$ & $\begin{array}{c}\text { Timber } \\
\text { production } \\
\text { purpose }(n=88, \\
35.5 \%)\end{array}$ & $\begin{array}{c}\text { Nature } \\
\text { management } \\
\text { purpose } \\
(n=47,19 \%)\end{array}$ & $\mathbf{F}$ & Sig. \\
\hline $\begin{array}{l}\text { Diversifying forest } \\
\text { management practices }\end{array}$ & 0.73242 & -0.70180 & -0.47078 & 205.943 & $<0.000$ \\
\hline Emphasis on nature & 0.13058 & -0.70837 & 1.01107 & 160.062 & $<0.000$ \\
\hline
\end{tabular}

\section{Forest management decisions and ownership objectives association}

The frequencies of groupings were cross-tabulated to explore the associations between owners' objectives and their forest management styles (Table 7). The total number of observations with valid group membership information for both groupings was 233 .

The main findings are that a large share in both economic and multiple objective groups aim to diversify their forest management: $39 \%$ and $60 \%$ among those groups, respectively, are classified among diversifying management style group. These represent 17.6 and $19.7 \%$, i.e. altogether $37.3 \%$ of all owners. Looking in another way, the results show that the group emphasizing economic use has actually management preferences of two kinds: managing their forests solely for timber (51\% within group) or diversifying the forest management used (39\% within group) in order to enhance the other forest functions alongside timber production. The distribution of respondents with the nature management preference is rather even within all objective groups. 
For every management style group, the biggest share was the one reflecting the respective objective best. Owners managing their forests predominantly for timber production also had economic use as their objective, and owners managing for nature purposes emphasized nature as their main goal. These are underlined in Table 7.

Table 7: Proportions of cross-tabulated clusterings of forest owner objectives and of clusters of their forest management style. Underlining indicates the biggest share of management style corresponding with respective objective.

\begin{tabular}{|c|c|c|c|c|c|c|}
\hline $\begin{array}{l}\text { Forest } \\
\text { Objectives of } \\
\text { forest owning }\end{array}$ & $\begin{array}{c}\text { Diversifying } \\
\text { forest } \\
\text { management, } \\
\%\end{array}$ & $\begin{array}{c}\text { Timber } \\
\text { production } \\
\text { purpose, \% }\end{array}$ & $\begin{array}{c}\text { Nature } \\
\text { management } \\
\text { purpose, \% }\end{array}$ & $\begin{array}{c}\text { Total, } \\
\%\end{array}$ & $\begin{array}{c}\text { Pearso } \\
\text { n Chi- } \\
\text { square, } \\
\chi 2\end{array}$ & Total \\
\hline $\begin{array}{l}\text { Emphasis on economic } \\
\text { use }\end{array}$ & 17.6 & $\underline{22.7}$ & 4.3 & 44.6 & $<0.000$ & $233^{\mathrm{a}}$ \\
\hline Emphasis on nature & 8.6 & 3.9 & 9.9 & 22.3 & & \\
\hline Multiple objectives & 19.7 & 7.7 & 5.6 & 33.0 & & \\
\hline Total & 45.9 & 34.3 & 19.7 & 100 & & \\
\hline
\end{tabular}

${ }^{\mathrm{a}}$ The total number of observations with valid group membership information for both groupings

Both typologies were cross-tabulated with socio-economic background variables and subsamples to rule out the possibility that observed differences between groups were due to the background of the respondents. Tested variables were age, gender, education level, form of possession of the holding, place of living, household income level, duration of forest possession, and subsample. From the tested variables gender caused statistically significant differences in the way the respondents were grouped. For forest ownership objective typology $p=0.023$ and for forest management style typology $p=0.046$. In the objective typology, the biggest group for women was multi-objective, for men it was timber production. Emphasis on nature was the smallest group for both women and men, with women having a slightly higher share in this. In the forest management style typology women have a clearly higher share in the diversifying group (55\%) than men (44\%). Women also more often want to manage their forests for nature $(25 \%)$ compared with men $(17 \%)$. There were significant results between subsamples for forest management style: $p=0.038$. However, the respondents were distributed so evenly in all cluster groups that we assume that it does not affect the results. There was a $45 \%$ share from both subsamples in the diversifying management practices group.

\section{Sum variables for information services about biodiversity protection and forest management planning}

Three sum variables were constructed for both services on biodiversity protection (Table 8) and FMP and related advisory services (Table 9). The sum variables for biodiversity related services were 'different information tools', 'direct interaction with an expert' and 'co-operation over forest holdings'. For forest management planning the sum variables were 'usability of FMP', 'decision support from FMP' and 'experience of restrictiveness of advisory services'. The last variable, although not a sum variable, was kept as it describes an essential characteristic of satisfaction with current services.

Table 8: Sum variables constructed based on services for biodiversity protection

\begin{tabular}{lr}
\hline & $\begin{array}{c}\text { Cronbach's } \\
\text { lpha }\end{array}$ \\
\hline Different information tools & $\mathbf{0 . 7 9 5}$ \\
\hline Map representing valuable sites & \\
\hline Texts describing valuable sites & $\mathbf{0 . 7 2 7}$ \\
\hline Photos describing valuable sites & \\
\hline Nature management recommendations supporting the positive progress of valuable sites & \\
\hline Direct interaction with an expert & $\mathbf{0 . 8 7 2}$ \\
\hline Telephone conversation with an expert about valuable sites in my forest & \\
\hline Meeting with an expert to discuss the valuable sites in my forest & \\
\hline Visit to valuable sites with an expert & \\
\hline
\end{tabular}


Meeting with the neighbouring forest owners and an expert to begin a nature management project crossing holding borders

An introductory visit with the neighbouring forest owners to valuable habitats located at the border between two neighbours

Table 9: Sum variables constructed based on satisfaction with forest management plan (FMP) and related advisory services

\begin{tabular}{cc}
\hline & $\begin{array}{c}\text { Cronbach's } \\
\text { alpha }\end{array}$ \\
\hline Usability of FMP & $\mathbf{0 . 7 6 8}$ \\
\hline My FMP is too technical, I don't understand it (scale inverted) & \\
\hline My FMP is illustrative enough & $\mathbf{0 . 7 4 1}$ \\
\hline Utilization of my FMP is easy & \\
\hline Decision support from FMP & - \\
\hline I am satisfied with the information the FMP gives about my forest holding and its \\
future possibilities
\end{tabular}

\section{Comparison of opinions about decision support services}

Comparison of means between different forest owner groups' opinions about information tools for biodiversity protection are presented in Table 10. Comparisons were calculated based on both forest ownership objectives and forest management style. For all sum variables (in Tables 8 and 9) there were statistically significant differences between the objective groups, varying from $p<0.001$ to $p=0.014$. Comparisons between forest management style groups had significant differences varying from $p<0.001$ to $p=0.022$. The post hoc tests are reported in Supplemental materials.

Information services for biodiversity protection were considered most positive by the group that emphasized nature values in both typologies. For them the opinions were more positive in forest management style typology (mean 3.8) than in objective typology (mean 3.4). Those emphasizing timber production in both typologies considered co-operation over forest holding the least necessary. The mean of the opinions about direct interaction with an expert was slightly negative (mean 2.9) for forest owners who manage their forest to produce timber.

Table 10: Comparison of different biodiversity related advisory services with forest ownership objective (OO) and forest management style (FMS). One-way ANOVA is calculated with sum variables for every column. Means are on a scale from 1 (not at all useful) to 5 (very useful). Statistically significant values are marked with asterisks (Pearson Chisquare $\mathrm{p}<0.05=* ; \mathrm{p}<0.01=* * ;$ and $\mathrm{p}<0.001=* * *)$.

\begin{tabular}{|c|c|c|c|c|c|}
\hline & & & $\begin{array}{l}\text { Different } \\
\text { information } \\
\text { tools }\end{array}$ & $\begin{array}{l}\text { Direct } \\
\text { interaction with } \\
\text { an expert }\end{array}$ & $\begin{array}{l}\text { Co- } \\
\text { operation } \\
\text { over forest } \\
\text { holdings }\end{array}$ \\
\hline \multirow{6}{*}{ 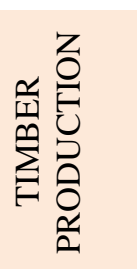 } & \multirow{3}{*}{$\begin{array}{c}\text { OO: Emphasis on economic } \\
\text { use }\end{array}$} & Mean & 3.44 & 3.18 & 2.66 \\
\hline & & $\mathrm{N}$ & 100 & 110 & 110 \\
\hline & & Std deviation & 0.95 & 1.03 & 1.08 \\
\hline & \multirow{3}{*}{$\begin{array}{l}\text { FMS: Timber production } \\
\text { purpose }\end{array}$} & Mean & 3.13 & 2.98 & 2.49 \\
\hline & & $\mathrm{N}$ & 76 & 81 & 82 \\
\hline & & Std deviation & 1.01 & 1.16 & 1.10 \\
\hline \multirow{4}{*}{ 宼器方 } & \multirow{4}{*}{ OO: Emphasis on nature } & Mean & 3.39 & 3.04 & 3.21 \\
\hline & & $\mathrm{N}$ & 54 & 55 & 56 \\
\hline & & Std deviation & 0.88 & 1.01 & 1.23 \\
\hline & & Mean & 3.76 & 3.51 & 3.47 \\
\hline
\end{tabular}




\begin{tabular}{|c|c|c|c|c|c|}
\hline & & $\mathrm{N}$ & 41 & 43 & 43 \\
\hline & $\begin{array}{c}\text { FMS: Nature management } \\
\text { purpose }\end{array}$ & & & & \\
\hline & & Std deviation & 0.86 & 0.91 & 1.16 \\
\hline & & Mean & 3.82 & 3.55 & 3.24 \\
\hline & OO: Multiple objectives & $\mathrm{N}$ & 77 & 77 & 78 \\
\hline & & Std deviation & 1.06 & 1.14 & 1.34 \\
\hline$\geq$ & & Mean & 3.71 & 3.27 & 3.06 \\
\hline 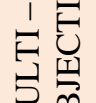 & $\begin{array}{l}\text { FMS: Diversifying forest } \\
\text { management }\end{array}$ & $\mathrm{N}$ & 105 & 110 & 110 \\
\hline$\Sigma \overline{0}$ & & Std deviation & 0.92 & 1.05 & 1.25 \\
\hline & & Mean & 3.55 & 3.26 & 2.98 \\
\hline & Total OO & $\mathrm{N}$ & 231 & 242 & 244 \\
\hline & & Std deviation & 0.98 & 1.08 & 1.23 \\
\hline 5 & & Mean & 3.52 & 3.21 & 2.94 \\
\hline & Total FMS & $\mathrm{N}$ & 222 & 234 & 235 \\
\hline & & Std deviation & 0.97 & 1.08 & 1.23 \\
\hline & & F & 10.119 & 10.119 & 6.744 \\
\hline & ANOVA OO & Sig. & 0.014* & $0.015 *$ & $0.001 * *$ \\
\hline & & Levene's test & 0.782 & 0.278 & 0.063 \\
\hline & & $\mathrm{F}$ & 10.119 & 3.873 & 10.791 \\
\hline & ANOVA FMS & Sig. & $<0.001 * * *$ & $0.022 *$ & $<0.001 * * *$ \\
\hline & & Levene's test & 0.514 & 0.377 & 0.646 \\
\hline
\end{tabular}

Comparison of means between different forest owner groups' opinions about forest management planning and related advisory services are presented in Table 11. In comparison with forest ownership objectives there were statistically significant differences between the groups for all tested sum variables, varying from $p<0.001$ to $p=0.044$. Comparisons between forest management style groups had significant differences between the groups for sum variables 'experience of restrictiveness of advisory services' $(p=0.009)$ and 'decision support from FMP' $(p=0.008)$. Conditions for using ANOVA were not fulfilled in later comparison of means for forest management style so a Welch's t-test was applied for significance testing.

Table 11: Comparison of satisfaction with forest management plan (FMP) and advisory services with forest ownership objective (OO) and forest management style (FMS). One-way ANOVA is calculated with sum variables for every column. Means are on a scale from 1 (totally disagree) to 5 (totally agree). Statistically significant values are marked with asterisks (Pearson Chi-square $\mathrm{p}<0.05=* ; \mathrm{p}<0.01=* *$; and $\mathrm{p}<0.001=* * *$ ).

\begin{tabular}{|c|c|c|c|c|c|}
\hline & & & $\begin{array}{c}\text { Usability of the } \\
\text { FMP }\end{array}$ & $\begin{array}{l}\text { Decision support } \\
\text { from FMP }\end{array}$ & $\begin{array}{l}\text { Experience of } \\
\text { restrictiveness of } \\
\text { advisory services }\end{array}$ \\
\hline \multirow{3}{*}{ 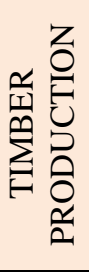 } & \multirow{2}{*}{$\begin{array}{l}\text { OO: Emphasis on } \\
\text { economic use }\end{array}$} & $\begin{array}{c}\text { Mean } \\
\mathrm{N}\end{array}$ & $\begin{array}{l}4.05 \\
102\end{array}$ & $\begin{array}{r}4.29 \\
106\end{array}$ & $\begin{array}{l}1.94 \\
107\end{array}$ \\
\hline & & Std deviation & 0.79 & 0.82 & 0.93 \\
\hline & $\begin{array}{l}\text { FMS: Timber } \\
\text { production } \\
\text { purpose }\end{array}$ & $\begin{array}{c}\text { Mean } \\
\text { N } \\
\text { Std deviation }\end{array}$ & $\begin{array}{c}4.09 \\
77 \\
0.88\end{array}$ & $\begin{array}{c}4.24 \\
82 \\
0.90\end{array}$ & $\begin{array}{c}1.80 \\
83 \\
0.85\end{array}$ \\
\hline \multirow{3}{*}{ 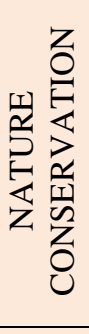 } & $\begin{array}{c}\text { OO: Emphasis on } \\
\text { nature }\end{array}$ & $\begin{array}{c}\text { Mean } \\
\text { N } \\
\text { Std deviation }\end{array}$ & $\begin{array}{c}3.63 \\
49 \\
0.93\end{array}$ & $\begin{array}{c}3.61 \\
51 \\
0.96\end{array}$ & $\begin{array}{c}2.34 \\
53 \\
1.07\end{array}$ \\
\hline & $\begin{array}{l}\text { FMS: Nature } \\
\text { management } \\
\text { purpose }\end{array}$ & $\begin{array}{c}\text { Mean } \\
\text { N }\end{array}$ & $\begin{array}{c}3.68 \\
44\end{array}$ & $\begin{array}{c}3.70 \\
46\end{array}$ & $\begin{array}{l}2.2 \\
46\end{array}$ \\
\hline & & Std deviation & 0.98 & 1.07 & 1.13 \\
\hline & & Mean & 3.99 & 4.23 & 2.05 \\
\hline
\end{tabular}




\begin{tabular}{|c|c|c|c|c|c|}
\hline \multirow{4}{*}{ 宫点 } & $\begin{array}{c}\text { OO: Multiple } \\
\text { objectives }\end{array}$ & $\begin{array}{c}\mathrm{N} \\
\text { Std deviation }\end{array}$ & $\begin{array}{c}77 \\
0.75\end{array}$ & $\begin{array}{c}78 \\
0.75\end{array}$ & $\begin{array}{c}80 \\
0.86\end{array}$ \\
\hline & FMS: & Mean & 3.91 & 4.22 & 2.18 \\
\hline & Diversifying & $\mathrm{N}$ & 105 & 106 & 109 \\
\hline & management & Std deviation & 0.68 & 0.69 & 0.90 \\
\hline \multirow{14}{*}{ 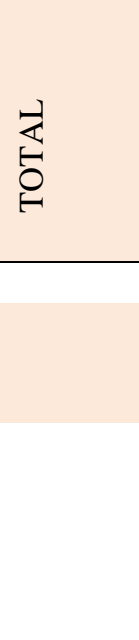 } & \multirow{3}{*}{ Total OO } & Mean & 3.94 & 4.12 & 2.07 \\
\hline & & $\mathrm{N}$ & 228 & 235 & 240 \\
\hline & & Std deviation & 0.82 & 0.87 & 0.95 \\
\hline & \multirow{3}{*}{ Total FMS } & Mean & 3.93 & 4.12 & 2.05 \\
\hline & & $\mathrm{N}$ & 226 & 234 & 238 \\
\hline & & Std deviation & 0.82 & 0.87 & 0.95 \\
\hline & \multirow[t]{3}{*}{ ANOVA OO } & $\mathrm{F}$ & 4.596 & 12.681 & 3.16 \\
\hline & & Sig. & $0.011 * *$ & $<0.001 * * * *$ & $0.044 *$ \\
\hline & & Levene's test & 0.088 & 0.095 & 0.076 \\
\hline & \multirow[t]{3}{*}{ ANOVA FMS } & F & - & - & 4.76 \\
\hline & & Sig. & - & - & $0.009 * *$ \\
\hline & & Levene's test & 0.001 & 0.003 & 0.057 \\
\hline & \multirow[t]{2}{*}{ Welch FMS } & $\mathrm{F}$ & - & - & - \\
\hline & & Sig. & 0.071 & $0.008 * *$ & - \\
\hline
\end{tabular}

Decision support offered by FMP was considered very positive in all groups and in both typologies (total means 4.1 in both typologies). The highest means for both typologies were in the group that emphasized timber production. The same group felt to the least extent that the advisory services available restrict their forest management, although none of the groups agreed with this statement (all means under 2.5). The means of the individual sum variables for grouping were very similar despite the typology used for comparison. Among biodiversity related services (Table 10) there were more differences in means between objective and management style typologies in every cluster group than in forest management planning related services (Table 11).

\section{DISCUSSION}

When analysing the ownership objectives, we found that the biggest forest owner group (45\%) was those emphasizing economic use of their forests, the second largest those having multiple objectives (33\%) and the smallest was those emphasizing nature values (23\%). For the forest management style the largest group was 'diversifying management practices' $(46 \%)$. Clearly fewer respondents were in a group that aims for timber production (36\%). The smallest group was those managing their forests for nature (19\%). Though our grouping was assembled somewhat differently, these results are in line with other recent studies about Finnish FFO objectives (Hänninen et al. 2011; Haltia and Rämö 2017). When comparing these groupings, $18 \%$ of respondents had a combination of timber as their objective and diversifying as their forest management style. A share of $20 \%$ had multiple objectives for their forests and were also going to include nature management practices in their forest management. Altogether $46 \%$ of FFOs were considering applying multiobjective forest management. We also found out that these two groupings corresponded very well to each other; forest owners seem to prefer a management style reflecting their objectives. These results are applicable in Finland, but cannot (and are not meant to) be generalized to other countries as such. For example, the dynamics between instrumental and intrinsic values among forest owners may be different outside Finland. However, also a wider European study highlights the multiple objectives of forest owners; forest owners increasingly manage their forests for multiple objectives such as maintaining ecosystems instead of only exploiting the timber (Feliciano et al. 2017).

Thus, the preferred way to manage the forest demonstrated ownership objectives, as hypothesized in the first research question. Takala et al. (2017) argued that genuine objectives have an effect on practical management decisions. Our results indicate that although a great share of FFOs still aim for income from timber selling, they are more interested in doing that only alongside maintaining and not compromising other forest functions such as recreation and biodiversity 
protection. The generic economic objective of an FFO may stand for different management intentions for different FFOs and hence needs to be further surveyed in advisory services. Alike, multi-objective owners are a heterogeneous group, with often a large variability among the owners in the mixture of objectives they have and in the relative importance they give to their objectives (Blanco et al. 2015). Rather similar share of respondents from all objective groups were interested in nature management albeit the biggest share is those emphasising nature as their objective. These management preferences cannot be found out based on the FFO's objectives but they need to be asked in more concrete way in advising services.

The second research question dealt with the problem of directing forest advisory services to FFOs with different objectives. The group emphasizing nature values in both typologies considered biodiversity related information about their forest more necessary than other groups. They were also less satisfied with the usability of the FMP and the decision support it gives related to the use and management of their forests than the other groups. This is understandable since the majority of current planning and management services are concentrated on maximizing timber harvests (Mattila et al. 2013). It is also in line with the conclusions of earlier studies (Boon et al. 2004; Ingemarson et al. 2006).

The different information tools (e.g. maps and photos) for biodiversity protection were considered the most useful of three sum variables, which is probably explained by the familiarity of these instruments and their use. Kumela et al. (2013) found that forest service providers in Finland had, a few years ago, very little if any tools or means for planning for nature values or comparing the economic or ecological consequences of different management operations. Thus it is obvious that lack of nature-oriented planning tools for decision-making situations unintentionally directs advisory services solely towards timber production.

In Finland about 45\% of forest holdings have an FMP in place (Hänninen et al. 2011). In this study, however, the share of forest owners having an FMP in place was over 75\%, so it seems that the questions were mainly answered by those having an FMP. Forest management planning in its current form best serves timber production objectives (Kurttila et al. 2010), and it is thus logical that forest owners targeting timber production found the tool most useful. Furthermore, the FMP has been such a fundamental instrument in Finnish forestry (their production was strongly supported by the state) that many owners consider it very useful even if it does not fully take their objectives into account. The result that the timber production group finds advisory services the least restricting is also a logical consequence of advisory services still concentrating mainly on timber production purposes.

Takala et al. (2017) found in their recent study that the importance given to different objectives asked in the survey may have been a rather general appreciation compared with actual forest ownership objectives. This phenomenon may have affected our results about the share of multi-objective FFOs as well. Some forest owners, despite being categorized as multi-objective in this study, do not manage their forests for multiple purposes. On the other hand, a positive attitude of FFOs towards forest functions other than timber production could be seen as a motivation to take them into account in their management decisions. It is also possible that since there are very few services related to, for example, biodiversity or recreational value management, FFOs are not used to thinking that they could carry out other forest management than timber production.

Based on the rather positive rating the respondents gave in our study to the biodiversity-related information services it can be assumed that although timber production is the main goal for many FFOs, they anyhow are willing to gain knowledge for comparing forest management alternatives. This new information might also make them adapt their management practices towards more close-to-nature ones as they notice that they can be executed in line with their main goals. Those FFOs who want to maintain multiple forest functions at the same time probably currently lack information for integrating their possibly conflicting objectives. For them, adding biodiversity-related information to services might help to fulfil all aspects of their ownership objectives.

In previous studies, it has been found that policy instruments, such as extension services, education or financial instruments, are more effective if they are suited to the objectives of the forest owners (Favada et al. 2009). To ensure the sustainable provision of multiple ecosystem services to benefit whole society, forest policy instruments, such as advisory services and communication campaigns, must comply with biodiversity and climate mitigation targets in the meantime with timber production goals. 
Targeting close-to-nature forest management assistance and potential cost-sharing programmes towards forest owners who already have these goals provides many ecosystem services to the society in a very cost-effective way (Kline et al. 2000). Increasing the promotion of natural and recreational values of forests in advisory services would motivate natureoriented and multi-objective forest owners to manage their forests (Bieling 2004) and hence contribute to the increased timber mobilization instead of shutting themselves totally off from timber market. Service offerings for nature-oriented FFOs should focus on technical and financial support programmes such as taxation measures and conservation easements (Côté et al. 2015) and, in the Finnish context, on the possibility to enter into a voluntary conservation contract. As securing the conservation of biodiversity also in production forests is important, financial instruments that motivate economically oriented FFOs should be optimized to support active nature management alongside timber production goals (Bieling 2004). In Finland, for example, state support for young stand improvement could be subject to introducing a minimum level of measurable nature management elements, such as leaving a mixture of broad-leaved tree species. As an example of a market-oriented tool, certification schemes (Bieling 2004) could still be a way to tighten the connection between timber production and nature management. Certification criteria could encourage more active nature management practices to be applied instead of the passive leave-aside practices.

Developing services for forest owners with diverse socio-economic backgrounds, information needs and objectives is important (Bieling 2004). Future forest owners value good availability of services and active communication with forestry professionals (Korhonen et al. 2012). Sharing values about how forestry should be carried out is an important factor in customer loyalty towards timber procurers (Staal Wästerlund and Kronholm 2016). Hence being able to offer advisory and harvesting services that are in line with FFOs views may become a crucial factor in timber procurement, competition for which is expected to intensify.

When testing the socio-economic background variables with cluster groups, only gender had statistically significant results, in contrast to many earlier studies (see e.g. Lidestav and Ekström 2000; Nordlund and Westin 2010; Häyrinen et al. 2015). Our results are in line with earlier studies about women directing their objectives more towards nature than pure economic gains (Lidestav and Ekström 2000; Häyrinen et al. 2015). Since it is expected that there will be more female forest owners in the future (Follo et al. 2016), it is important for service development to consider the general trend of women tending to value nature stronger alongside economic use. Taking this into account, finding and implementing practices that combine timber production and enhance nature and recreational values might be the decisive factor for forest service providers when promoting for increasing harvesting amounts (Kumela et al. 2013). Also the finding that the respondents were evenly distributed in cluster groups regardless of whether they have a conservation contract or not bolsters the result of multi-objectivity being a general trend.

The response rate of the study, although rather low, is comparable with the level of other survey studies in recent years. We compared the respondents of the study with information about forest owners in general in Finland, and they illustrate similar socio-demographic patterns. However, as surveys require effort from the respondents, it is likely that our respondents are more interested in and aware of forest issues than FFOs in average. To a certain degree, the observed results are dependent on the subjective assumptions made in the analysis, especially regarding interpreting and naming the cluster groups. Thus the analysis was discussed among the authors to ensure the greatest objectivity of the interpretation.

This study contributes to a practice-relevant research agenda and our results are applicable in developing practical forest advisory services. Although there is still a need for more research and piloting on how to help FFOs articulate different objectives or management guidelines, it can already be recommended that planning and advising for close-to-nature forest management should be the default practice when advising forest owners.

\section{CONCLUSIONS}

This study confirms earlier knowledge about the importance of taking nature values or other forest owner preferences into account when planning and executing forest management operations. A large share of forest owners are willing to manage their forest combining economic and other objectives in an equal manner. Supporting this tendency costeffectively helps to maintain biodiversity and provision of multiple ecosystem services from the production forests. The 
results suggest that policy measures supporting nature management alongside economic objectives would motivate multiobjective FFOs to manage their forests more actively.

Forestry service providers carry a great responsibility for promoting and providing advice about the nature management approach. Forest management planning and advisory services must provide information and alternatives for forest uses other than timber production. Assisting FFOs to manage forest in different ways may also clarify and articulate the objectives they have for their forests. Thereby our results about the connection between practical management decisions and ownership objectives also enhance policy implementation and the effectiveness of policy measures.

We recommend planning and advising for multi-objective forest management should be the default practice instead of the prevailing practice in Finland emphasising timber production. The service-providing organisations are in a key role for further developing nature-oriented and multi-objective forest management services that answer the expectations of FFOs. Offering services such as light selection felling and planning of retention tree areas from the beginning of the rotation period should be as usual a part of the business as any other more traditional forest management scheme. Possibilities to participate in conservation programmes or protect the forest should also be presented in an equal manner if the FFO has nature objectives.

However, solving the difficulty of defining FFO objectives in a practical forest advising situation needs more research and pilot projects with forest service providers. Developing means to visualize and compare the alternative forest management regimes and their consequences is also important.

\section{Acknowledgements}

Part of the work has been carried out in the project 311 340/2013, funded by the Finnish Ministry of Agriculture and Forestry. The Finnish Cultural Foundation, South Savo Regional Fund and the Foundation of South-West Finland's Forest Management Associations have also funded the work. We want to thank Mikko Kurttila, Markus Nissinen, Eeva Primmer, Salla Rantala, Outi Ratamäki and the Finnish Forest Centre, Pohjois-Karjala office, for their input to data collection, and all survey respondents for their participation in the study.

\section{REFERENCES}

Amacher GS, Koskela E, Ollikainen M, Conway MC (2002) Bequest Intentions of Forest Landowners: Theory and Empirical Evidence. Am J Agric Econ 84:1103-1114. doi: 10.1111/1467-8276.00371

Auvinen A, Hildén M, Toivonen H, et al (2007) Evaluation of the Finnish National Biodiversity Action Plan 19972005. Monographs of the Boreal Environment Research 29.

Bieling C (2004) Non-industrial private-forest owners: Possibilities for increasing adoption of close-to-nature forest management. Eur J For Res 123:293-303. doi: 10.1007/s10342-004-0042-6

Blanco V, Brown C, Rounsevell M (2015) Characterising forest owners through their objectives, attributes and management strategies. Eur J For Res. doi: 10.1007/s10342-015-0907-x

Boon TE, Meilby H, Thorsen BJ (2004) An Empirically Based Typology of Private Forest Owners in Denmark: Improving Communication Between Authorities and Owners. Scand J For Res 19:45-55. doi: $10.1080 / 14004080410034056$

Butler SM, Butler BJ, Markowski-Lindsay M (2016) Family Forest Owner Characteristics Shaped by Life Cycle, Cohort, and Period Effects. Small-scale For 1-18. doi: 10.1007/s11842-016-9333-2

Conway MC, Amacher GS, Sullivan J, Wear D (2003) Decisions nonindustrial forest landowners make: an empirical examination. J For Econ 9:181-203. doi: 10.1078/1104-6899-00034

Côté M-A, Gilbert D, Nadeau S (2016) Impact of Changes in the Sociological Characteristics of Small-Scale Forest Owners on Timber Harvesting Behavior in Quebec, Canada. Small-scale For 15:375-392. doi: 10.1007/s11842016-9328-Z

Côté M-A, Gilbert D, Nadeau S (2015) Characterizing the profiles, motivations and behaviour of Quebec's forest owners. For Policy Econ 59:83-90. doi: 10.1016/j.forpol.2015.06.004

Cronbach LJ (1951) Coefficient alpha and the internal structure of tests. Psychometrika 16:297-334. doi: 10.1007/BF02310555 
Emtage N, Herbohn J, Harrison S (2007) Landholder Profiling and Typologies for Natural Resource-Management Policy and Program Support: Potential and Constraints. Environ Manage 40:481-492. doi: 10.1007/s00267-0050359-z

Fabrigar LR, Wegener DT (2012) Exploratory Factor Analysis: understanding statistics. Oxford University Press cop. 2012

Favada IM, Karppinen H, Kuuluvainen J, et al (2009) Effects of timber prices, ownership objectives, and owner characteristics on timber supply. For Sci 55:512-523.

Feliciano D, Bouriaud L, Brahic E, et al (2017) Understanding private forest owners' conceptualisation of forest management: Evidence from a survey in seven European countries. J Rural Stud 54:162-176. doi: 10.1016/j.jrurstud.2017.06.016

Ficko A, Lidestav G, Ní Dhubháin Á, et al (2017) European private forest owner typologies: A review of methods and use. For Policy Econ 0-1. doi: 10.1016/j.forpol.2017.09.010

Finnish Forest Research Institute (2014) Finnish Statictical Yearbook of Forestry 2014. Tammerprint Oy

Follo G, Lidestav G, Ludvig A, et al (2016) Gender in European Forest Ownership and Management - Reflections on Women as "New Forest Owners." Scand J For Res 0:1-36. doi: 10.1080/02827581.2016.1195866

Gamborg C, Larsen JB (2003) "Back to nature" - A sustainable future for forestry? For Ecol Manage 179:559-571. doi: 10.1016/S0378-1127(02)00553-4

Government of Finland (2014) Finnish Government Resolution on the Continuation of Forest Biodiversity Programme for Southern Finland 2014-2025. 5.6.2014 [in Finnish].

Graham RT, Jain TB (1998) Silviculture's Role in Managing Boreal Forests. Conserv Ecol 2:art8. doi: 10.5751/ES00053-020208

Gruen TW, Summers JO, Acito F (2000) Relationship Marketing Activities, Commitment, and Membership Behaviors in Professional Associations. J Mark 64:34-49. doi: 10.1509/jmkg.64.3.34.18030

Haltia E, Rämö A-K (2017) Miksi metsien taloudellisia mahdollisuuksia jätetään käyttämättä? - Metsänomistajakyselyn tuloksia [Why do the economic opportunities of forests remain untapped? - Forest Owner Survey results.

Haltia E, Rämö A-K, Pynnönen S, et al (2017) Miksi metsien taloudellisia mahdollisuuksia jätetään käyttämättä? Metsänomistejin aktiivisuus ja siihen vaikuttaminen [Why do the economic opportunities of forests remain untapped? - forest owner activity and means to influence it].

Harlio A (2017) Voluntary biodiversity conservation optimization in agricultural and forest environments. University of Helsinki, Faculty of Biological and environmental sciences

Hartley MJ (2002) Rationale and methods for conserving biodiversity in plantation forests. For Ecol Manage 155:8195. doi: 10.1016/S0378-1127(01)00549-7

Hokajärvi R, Hujala T, Leskinen LA, Tikkanen J (2009) Effectiveness of sermon policy instruments: Forest management planning practices applying the activity theory approach. Silva Fenn 43:889-906.

Hujala T, Kurttila M, Karppinen H (2013) Customer Segments Among Family Forest Owners: Combining Ownership Objectives and Decision-Making Styles. Small-scale For 12:335-351. doi: 10.1007/s11842-012-9215-1

Hujala T, Pykäläinen J, Tikkanen J (2007) Decision making among Finnish non-industrial private forest owners: The role of professional opinion and desire to learn. Scand J For Res 22:454-463. doi: 10.1080/02827580701395434

Hänninen H, Karppinen H, Leppänen J (2011) Suomalainen metsänomistaja 2010 [Finnish Forest Owner 2010]. Working Papers of the Finnish Forest Research Institute 208.

Häyrinen L, Mattila O, Berghäll S, Toppinen A (2015) Forest Owners' Socio-demographic Characteristics as Predictors of Customer Value: Evidence from Finland. Small-scale For 14:19-37. doi: 10.1007/s11842-014-9271-9

Ingemarson F, Lindhagen A, Eriksson L (2006) A typology of small-scale private forest owners in Sweden. Scand J For Res 21:249-259. doi: 10.1080/02827580600662256

Jain AK (2010) Data clustering: 50 years beyond K-means. Pattern Recognit Lett 31:651-666. doi: 10.1016/j.patrec.2009.09.011

Jenkins CN, Joppa L (2009) Expansion of the global terrestrial protected area system. Biol Conserv 142:2166-2174. doi: 10.1016/j.biocon.2009.04.016

Karppinen H (2012) New forest owners and owners-to-be: Apples and oranges? Small-scale For 11:15-26. doi: 10.1007/s11842-011-9165-Z

Kaufman L, Rousseeuw PJ (1990) Finding Groups in Data: An Introduction to Cluster Analysis. New York (NY) : Wiley 1990.

Kline JD, Alig RJ, Johnson RL (2000) Fostering the production of nontimber services among forest owners with heterogeneous objectives. For Sci 46:302-311.

Korhonen K, Hujala T, Kurttila M (2012) Reaching forest owners through their social networks in timber sales. Scand J For Res 27:88-99. doi: 10.1080/02827581.2011.631935

Kumela H, Hujala T, Pykäläinen J, Rantala M (2013) Metsänomistajille tarjottavat luontoarvopalvelut : nykytila ja kehitysnäkymiä [Nature value related services offered to forest owners: present state and prospects]. Working Papers of the Finnish Forest Research Institute 253.

Kurttila M, Korhonen K, Hänninen H, Hujala T (2010) Yksityismetsien metsäsuunnittelu 2010 - nykytilanne ja 
kehittämistarpeita [Forest mangement planning 2010 - present situation and development needs]. Working Papers of the Finnish Forest Research Institute 153.

Leppänen J (2010) Finnish family forest owner 2010 survey. Scand For Econ No 43:184-195.

Leppänen J, Sevola Y (2014) Pien- ja suuromistuksia entistä enemmän [Smallest and greatest forest holdings more common than before]. Forest statistical bulletin 6/2014 [Metsätilastotiedote] Finnish Forest Research Institute Metla

Lidestav G, Ekström M (2000) Introducing Gender in Studies on Management Behaviour Among Non-industrial Private Forest Owners. Scand J For Res 15:378-386. doi: 10.1080/028275800448011

MacCallum RC, Widaman Keith F, Zhang Shaobo, Hong Sehee (1999) Sample Size in Factor Analysis. Psychol Methods 4:84-99.

Margules CR, Pressey RL (2000) Systematic conservation planning. Nature 405:243-253. doi: 10.1038/35012251

Markowski-Lindsay M, Catanzaro P, Milman A, Kittredge D (2016) Understanding Family Forest Land Future Ownership and Use: Exploring Conservation Bequest Motivations. Small-scale For 15:241-256. doi: $10.1007 / \mathrm{s} 11842-015-9320-\mathrm{z}$

Mattila O, Roos A (2014) Service logics of providers in the forestry services sector: Evidence from Finland and Sweden. For Policy Econ 43:10-17. doi: 10.1016/j.forpol.2014.03.003

Mattila O, Toppinen A, Tervo M, Berghäll S (2013) Non-industrial Private Forestry Service Markets in a Flux: Results from a Qualitative Analysis on Finland. Small-scale For 12:559-578. doi: 10.1007/s11842-012-9231-1

Metsämuuronen J (2011) Tutkimuksen tekemisen perusteet ihmistieteissä [Foundations of research in social sciences]. International Methelp Oy

Millennium Ecosystem Assessment (2005) Ecosystems and human well-being: Synthesis. Island Press, Washington, DC.

Ní Dhubháin Á, Maguire K, Farrelly N (2010) The harvesting behaviour of Irish private forest owners. For Policy Econ 12:513-517. doi: 10.1016/j.forpol.2010.05.008

Nordlund A, Westin K (2010) Forest Values and Forest Management Attitudes among Private Forest Owners in Sweden. Forests 2:30-50. doi: 10.3390/f2010030

Ovaskainen V, Hujala T, Hänninen H, Mikkola J (2017) Cost sharing for timber stand improvements: Inducement or crowding out of private investment? For Policy Econ 74:40-48. doi: 10.1016/j.forpol.2016.10.014

Palander T, Ovaskainen H, Tikkanen L (2009) Profiles of private forest owners and the importance of landscape-scale management in the timber trade process of Finnish wood procurement. Forestry 82:227-239. doi: 10.1093/forestry/cpp006

Paloniemi R, Hujala T, Rantala S, et al (2017) Integrating Social and Ecological Knowledge for Targeting Voluntary Biodiversity Conservation. Conserv Lett. doi: 10.1111/conl.12340

Paloniemi R, Tikka PM (2008) Ecological and social aspects of biodiversity conservation on private lands. Environ Sci Policy 11:336-346. doi: 10.1016/j.envsci.2007.11.001

Paloniemi R, Vainio A (2011) Legitimacy and empowerment: combining two conceptual approaches for explaining forest owners' willingness to cooperate in nature conservation. J Integr Environ Sci 8:123-138. doi: 10.1080/1943815X.2011.576682

Primmer E, Paloniemi R, Similä J, Tainio A (2014) Forest owner perceptions of institutions and voluntary contracting for biodiversity conservation: Not crowding out but staying out. Ecol Econ 103:1-10. doi: 10.1016/j.ecolecon.2014.04.008

Päivinen R, Lehtoviita J, Arnkil N (2017) Kestävää kasvua metsistä -tasapainoisesti tulevaisuuteen [Sustainable growth from forests - balanced way to future]. Tapion raportteja 16

Rassi P, Hyvärinen E, Juslén A, Mannerkoski I (2010) Suomen lajien uhanalaisuus - Punainen kirja 2010, The 2010 Red List of Finnish Species.

Rudnick D a, Ryan SJ, Beier P, et al (2012) The role of landscape connectivity in planning and implementing conservation and restoration priorities. Issues in Ecology 16

Silver EJ, Leahy JE, Weiskittel AR, et al (2015) An Evidence-Based Review of Timber Harvesting Behavior among Private Woodland Owners. J For 113:490-499. doi: 10.5849/jof.14-089

Staal Wästerlund D, Kronholm T (2016) Family Forest Owners' Commitment to Service Providers and the Effect of Association Membership on Loyalty. Small-scale For 1-19. doi: 10.1007/s11842-016-9359-5

Suomen Metsäkeskus (2016) Pohjois-Karjalan metsäohjelma 2016-2020 [Regional Forest Programme of Northern Karelia 2016-2020]. Suomen Metsäkeskus ( Forest Centre)

Takala T, Hujala T, Tanskanen M, Tikkanen J (2017) Forest owners' discourses of forests: Ideological origins of ownership objectives. J Rural Stud 51:1-14. doi: 10.1016/j.jrurstud.2017.01.014

Tittensor DP, Walpole M, Hill SLL, et al (2014) Biodiversity Targets. Science (80- ) 346:241-245. doi: $10.1126 /$ science. 1257484

(2013) Forest Act 1093/1996. 


\section{SUPPLEMENTAL MATERIALS}

Table 1. Original survey question statements and response alternatives (translated from Finnish) used for factoring of forest ownership objectives

\begin{tabular}{|c|c|c|c|c|c|}
\hline $\begin{array}{l}\text { What kind of objectives do you have for the } \\
\text { use of your forests? } \\
\text { Please choose one on each row. }\end{array}$ & $\begin{array}{l}\text { Very } \\
\text { important } \\
5\end{array}$ & $\begin{array}{l}\text { Fairly } \\
\text { Important } \\
4\end{array}$ & $\begin{array}{l}\text { Indifferent } \\
\quad 3\end{array}$ & $\begin{array}{l}\text { Slightly } \\
\text { important } \\
2\end{array}$ & $\begin{array}{l}\text { Not at all } \\
\text { important } \\
1\end{array}$ \\
\hline \multicolumn{6}{|l|}{ Picking berries, mushrooms and other goods } \\
\hline \multicolumn{6}{|l|}{ Recreational values } \\
\hline \multicolumn{6}{|l|}{ Securing the availability of clean water } \\
\hline \multicolumn{6}{|l|}{ Securing or enhancing scenic values } \\
\hline \multicolumn{6}{|l|}{$\begin{array}{l}\text { Carbon sequestration and maintaining carbon } \\
\text { sinks to mitigate climate change }\end{array}$} \\
\hline \multicolumn{6}{|l|}{ Safeguarding the biodiversity of my forest } \\
\hline \multicolumn{6}{|l|}{ Maximizing economic profit } \\
\hline $\begin{array}{l}\text { Timber production, I mainly produce saw log } \\
\text { timber, pulp wood and fires wood in my forest }\end{array}$ & & & & & \\
\hline
\end{tabular}

Table 2. Original survey question statements and response alternatives (translated from Finnish) used for factoring of forest management style.

\begin{tabular}{|c|c|c|c|c|c|}
\hline $\begin{array}{l}\text { How likely it is that you will put following forest } \\
\text { management measures and services supporting } \\
\text { them into operation within next five years? }\end{array}$ & $\begin{array}{c}\text { Very } \\
\text { likely } \\
5\end{array}$ & $\begin{array}{l}\text { Fairly } \\
\text { likely } \\
4\end{array}$ & $\begin{array}{l}\text { Indifferent } \\
\quad 3\end{array}$ & $\begin{array}{c}\text { Fairly } \\
\text { unlikely } \\
\quad 2 \\
\end{array}$ & $\begin{array}{c}\text { Very } \\
\text { unlikely } \\
1\end{array}$ \\
\hline \multicolumn{6}{|l|}{$\begin{array}{l}\text { I will obtain a forest management plan (FMP) focusing } \\
\text { on uneven-aged management }\end{array}$} \\
\hline \multicolumn{6}{|l|}{$\begin{array}{l}\text { I will renew my FMP if there are new focuses } \\
\text { available, even it does not expire yet }\end{array}$} \\
\hline \multicolumn{6}{|l|}{ I will obtain a multi-objective FMP for my forests } \\
\hline \multicolumn{6}{|l|}{$\begin{array}{l}\text { I will obtain a harvesting plan that utilizes uneven-aged } \\
\text { harvesting methods (light selection felling or small- } \\
\text { area clear felling) }\end{array}$} \\
\hline \multicolumn{6}{|l|}{$\begin{array}{l}\text { I apply both so-called traditional and alternative forest } \\
\text { management regimes }\end{array}$} \\
\hline \multicolumn{6}{|l|}{$\begin{array}{l}\text { I will leave more retention trees in a felling area than is } \\
\text { required by minimum requirements of the PEFC Forest } \\
\text { certification }\end{array}$} \\
\hline \multicolumn{6}{|l|}{ I preserve selected areas of my forest holding } \\
\hline \multicolumn{6}{|l|}{$\begin{array}{l}\text { I will obtain an FMP focusing on nature management, } \\
\text { including i.a. surveying of nature values and } \\
\text { recommendations for their maintenance and } \\
\text { enhancement }\end{array}$} \\
\hline \multicolumn{6}{|l|}{$\begin{array}{l}\text { I will participate in an environmental restoration } \\
\text { project or start my own }\end{array}$} \\
\hline \multicolumn{6}{|l|}{ I manage my forests in a game-friendly manner } \\
\hline $\begin{array}{l}\text { I only apply so-called alternative forest management } \\
\text { regimes, such as uneven-aged stands }\end{array}$ & & & & & \\
\hline
\end{tabular}


Table 3. Original survey question (translated from Finnish) used to construct sum variables on services for biodiversity protection. The statements excluded from the sum variables are written in grey.

\begin{tabular}{|c|c|c|c|c|c|}
\hline $\begin{array}{l}\text { How useful do you consider the following services for your decision making } \\
\text { about safeguarding and enhancing the biodiversity in your forest? }\end{array}$ & $\begin{array}{c}\text { Very } \\
\text { useful } \\
5\end{array}$ & 4 & 3 & 2 & $\begin{array}{c}\text { Not at } \\
\text { all } \\
\text { useful } \\
1\end{array}$ \\
\hline \multicolumn{6}{|l|}{ Map representing valuable sites of my forest } \\
\hline \multicolumn{6}{|l|}{ Texts describing valuable sites of my forest } \\
\hline \multicolumn{6}{|l|}{ Photos describing valuable sites of my forest } \\
\hline \multicolumn{6}{|l|}{ Assessment of the future development of the valuable sites in my forest } \\
\hline \multicolumn{6}{|l|}{$\begin{array}{l}\text { Nature management recommendations supporting the positive progress of } \\
\text { valuable sites }\end{array}$} \\
\hline \multicolumn{6}{|l|}{ Mapping of the sites potentially suitable for METSO-contracting } \\
\hline \multicolumn{6}{|l|}{$\begin{array}{l}\text { Alternative calculations about the economic consequences (income and costs) } \\
\text { of entering into a METSO-contract or keeping the forest in production use }\end{array}$} \\
\hline \multicolumn{6}{|l|}{ Telephone conversation with an expert about valuable sites in my forest } \\
\hline \multicolumn{6}{|l|}{ Meeting with an expert to discuss the valuable sites in my forest } \\
\hline \multicolumn{6}{|l|}{$\begin{array}{l}\text { Meeting with the neighbouring forest owners and an expert to begin a nature } \\
\text { management project crossing holding borders }\end{array}$} \\
\hline \multicolumn{6}{|l|}{$\begin{array}{l}\text { An introductory visit with the neighbouring forest owners to valuable habitats } \\
\text { located at the border between two neighbours }\end{array}$} \\
\hline \multicolumn{6}{|l|}{$\begin{array}{l}\text { Computer visualizations about the development of my forest with different } \\
\text { management choices }\end{array}$} \\
\hline $\begin{array}{l}\text { Real time chat over internet with an expert about the valuable sites of my } \\
\text { forests, supported by a shared map on computer }\end{array}$ & & & & & \\
\hline
\end{tabular}

Table 4. Original survey question (translated from Finnish) used to construct sum variables on satisfaction with forest management plan (FMP) and related advisory services. The statements excluded from the sum variables are in grey.

\begin{tabular}{|c|c|c|c|c|c|}
\hline What do you think about following statements? & $\begin{array}{c}\text { Strongly } \\
\text { agree } \\
5\end{array}$ & 4 & 3 & 2 & $\begin{array}{c}\text { Strongly } \\
\text { disagree } \\
1\end{array}$ \\
\hline \multicolumn{6}{|l|}{$\begin{array}{l}\text { I am satisfied with the information the FMP gives about my forest holding and its } \\
\text { future possibilities }\end{array}$} \\
\hline \multicolumn{6}{|l|}{ My FMP is illustrative enough (it includes i.a. suitable maps and graphs) } \\
\hline \multicolumn{6}{|l|}{ Utilization of my FMP is easy } \\
\hline \multicolumn{6}{|l|}{ My FMP is too technical, and I don't understand it } \\
\hline \multicolumn{6}{|l|}{$\begin{array}{l}\text { I wish my FMP would include pictures about how my forest will look like after the } \\
\text { management operations planned in the FMP have been implemented }\end{array}$} \\
\hline \multicolumn{6}{|l|}{ My FMP does not correspond to my objectives or wishes } \\
\hline \multicolumn{6}{|l|}{ Legislation prevent me from managing my forests according my objectives } \\
\hline \multicolumn{6}{|l|}{$\begin{array}{l}\text { Land use planning and/or other regulations restrict the management of my forest } \\
\text { according my views too much }\end{array}$} \\
\hline \multicolumn{6}{|l|}{ Advisory services restrict me from managing my forest the way I would like to } \\
\hline \multicolumn{6}{|l|}{ I have enough knowledge to decide about the management of my forest property } \\
\hline \multicolumn{6}{|l|}{ My FMP helps me to decide about the management of my forests independently } \\
\hline \multicolumn{6}{|l|}{$\begin{array}{l}\text { Advisory services and information I receive about the management of my forest } \\
\text { property correspond to my objectives }\end{array}$} \\
\hline Forest certification enhances the forest biodiversity & & & & & \\
\hline
\end{tabular}


Table 5. Description of socio-demographic background information of the survey respondents. Differences in the background of the respondents between this study (N=298) and the Finnish Forest Owner Survey 2010 (N=6318) were tested with $\mathrm{X}^{2}$-test and $\mathrm{z}$-test. The results of $\mathrm{X}^{2}$-tests and z-tests are reported $(\mathrm{p}<0.05=* ; \mathrm{p}<0.01=* * ;$ and $\mathrm{p}<$ $0.001=* * *)$.

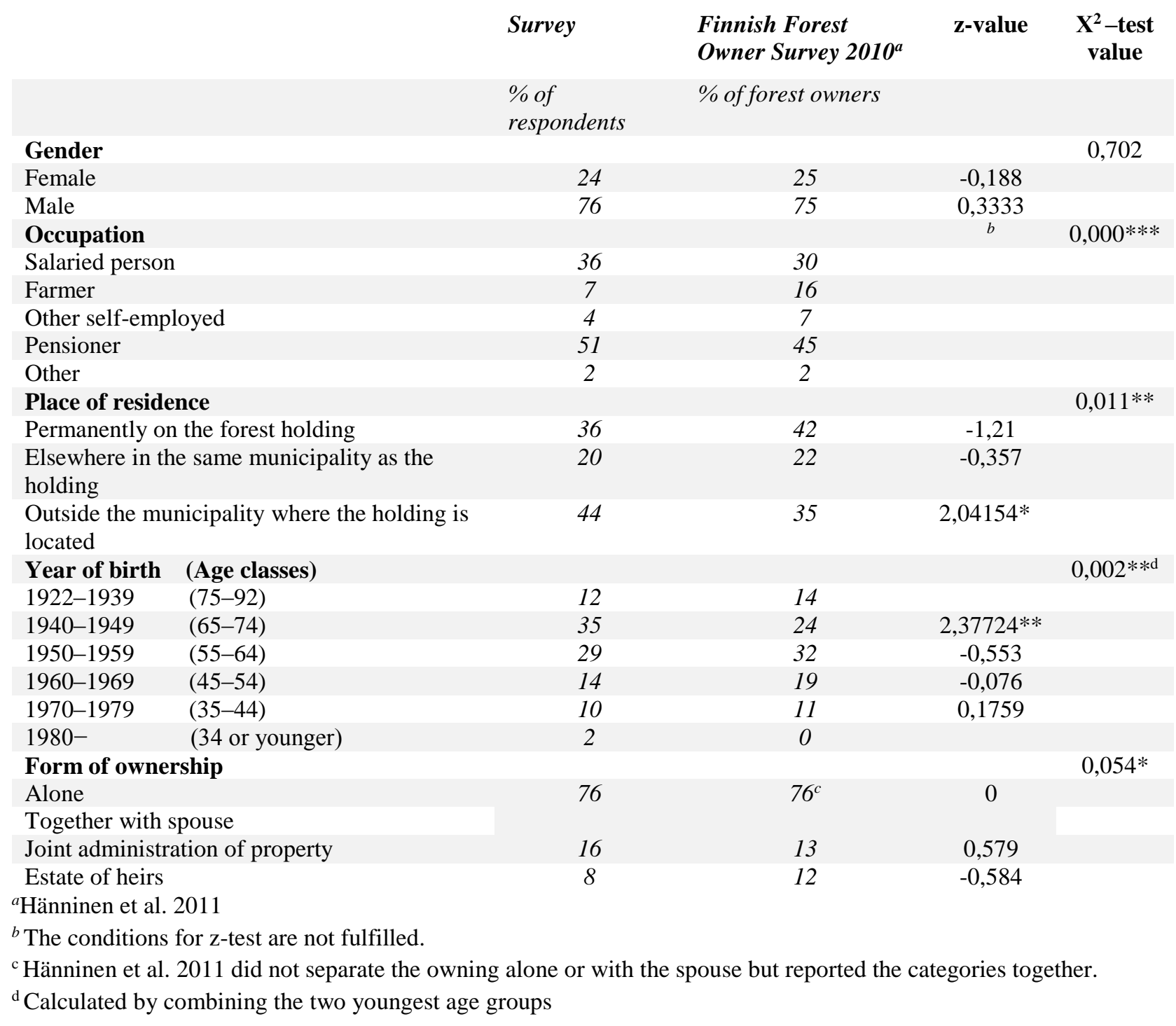

Table 6. Post hoc test Tukey HSD on comparison of different biodiversity related advisory services with forest ownership objectives. Means are on a scale from 1 (not at all useful) to 5 (very useful). Statistically significant values of mean differences are marked with asterisks $\left(\mathrm{p}<0.05 *^{*} ; \mathrm{p}<0.01=* *\right.$; and $\left.\mathrm{p}<0.001=* * *\right)$.

Group 1

Emphasis on economic use

\begin{tabular}{|c|c|c|c|c|}
\hline & & $\begin{array}{c}\text { vs } \\
\text { Group } 2 \\
\text { Emphasis on nature }\end{array}$ & $\begin{array}{c}\text { vs } \\
\text { Group 3 } \\
\text { Multiple objectives }\end{array}$ & $\begin{array}{c}\text { vs } \\
\text { Group } 3\end{array}$ \\
\hline \multirow{3}{*}{$\begin{array}{l}\text { Different } \\
\text { information tools }\end{array}$} & Sig. & 0.948 & $0.029 *$ & $0.036 *$ \\
\hline & Mean difference $(\mathrm{I}-\mathrm{J})$ & 0.05111 & -0.37818 & -0.42929 \\
\hline & Std. Error & 0.16396 & 0.14720 & 0.17233 \\
\hline $95 \%$ Confidence & Lower Bound & -0.3357 & -0.7255 & -0.8359 \\
\hline Interval & Upper Bound & 0.4379 & -0.0309 & -0.0227 \\
\hline
\end{tabular}

Group 1

Group 2

$-0.0227$ 


\begin{tabular}{|c|c|c|c|c|}
\hline \multirow{3}{*}{$\begin{array}{l}\text { Direct interaction } \\
\text { with an expert }\end{array}$} & Sig. & 0.685 & $0.057^{*}$ & $0.019 * *$ \\
\hline & Mean difference (I-J) & 0.14545 & -0.36364 & -0.50909 \\
\hline & Std. Error & 0.17533 & 0.15775 & 0.18743 \\
\hline \multirow{2}{*}{$\begin{array}{l}95 \% \text { Confidence } \\
\text { Interval }\end{array}$} & Lower Bound & -0.2680 & -0.7357 & -0.9511 \\
\hline & Upper Bound & 0.5589 & 0.0084 & -0.0670 \\
\hline \multirow{3}{*}{$\begin{array}{l}\text { Co-operation over } \\
\text { forest holdings }\end{array}$} & Sig. & $0.016^{*}$ & $0.004^{*}$ & 0.989 \\
\hline & Mean difference (I-J) & -0.55065 & -0.57995 & -0.02930 \\
\hline & Std. Error & 0.19736 & 0.17797 & 0.21058 \\
\hline $95 \%$ Confidence & Lower Bound & -1.0161 & -0.9996 & -0.5259 \\
\hline Interval & Upper Bound & -0.0852 & -0.1603 & 0.4673 \\
\hline
\end{tabular}

Table 7. Post hoc test Tukey HSD on comparison of different biodiversity related advisory services with forest management style. Means are on a scale from 1 (not at all useful) to 5 (very useful). Statistically significant values of mean differences are marked with asterisks $(\mathrm{p}<0.05=* ; \mathrm{p}<0.01=* *$; and $\mathrm{p}<0.001=* * *)$.

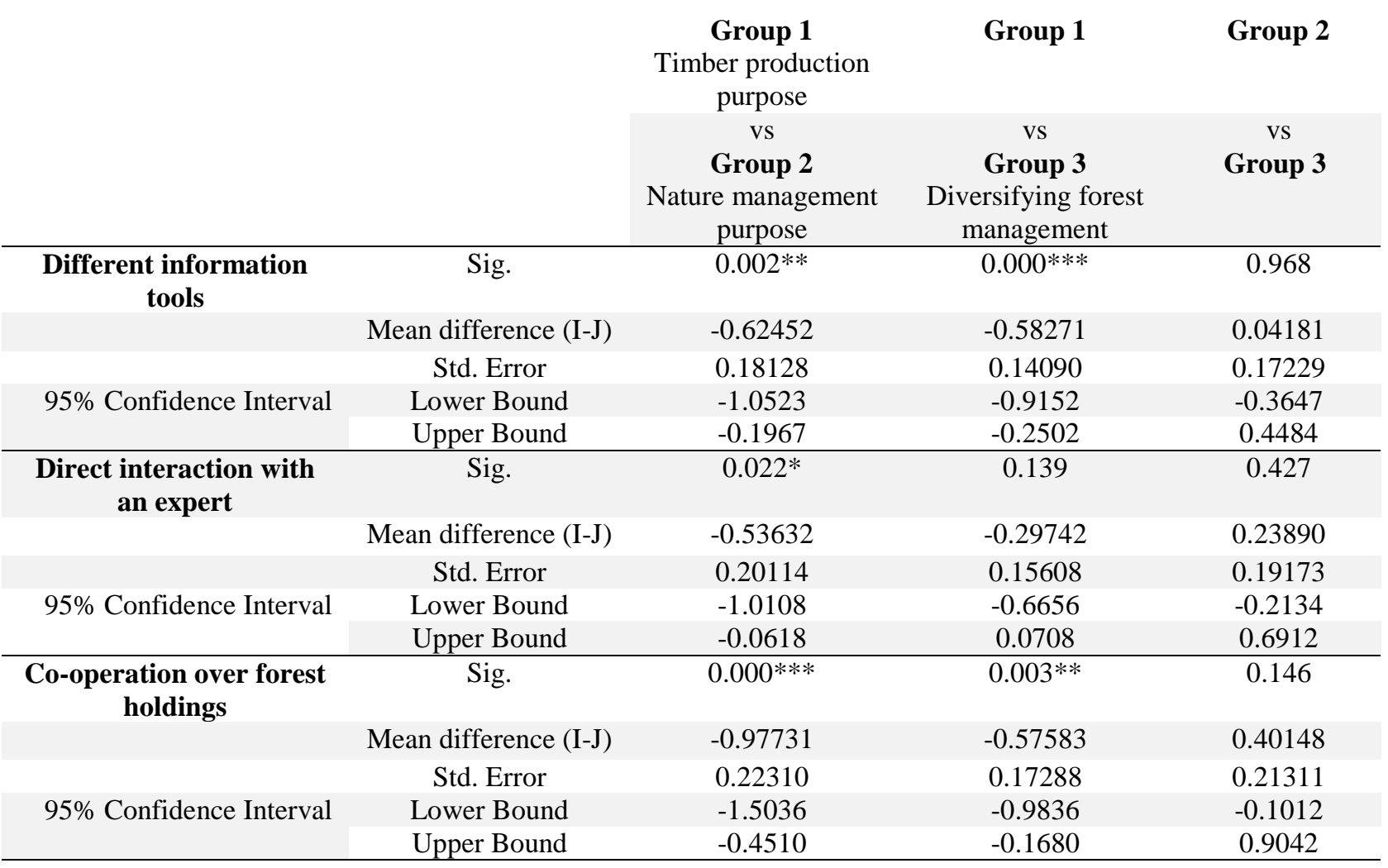

Table 8. Post hoc test Tukey HSD on comparison of satisfaction with forest management plan (FMP) and advisory services with forest ownership objectives. Means are on a scale from 1 (not at all useful) to 5 (very useful). Statistically significant values of mean differences are marked with asterisks $(\mathrm{p}<0.05=* ; \mathrm{p}<0.01=* *$; and $\mathrm{p}<0.001=* * *)$.

\begin{tabular}{ccccc} 
& $\begin{array}{c}\text { Group 1 } \\
\text { Emphasis on economic use }\end{array}$ & $\begin{array}{c}\text { Group 1 } \\
\text { vs } \\
\text { Group 2 } \\
\text { Emphasis on nature }\end{array}$ & $\begin{array}{c}\text { vs } \\
\text { Group 3 } \\
\text { Multiple } \\
\text { objectives }\end{array}$ & $\begin{array}{c}\text { Group 2 } \\
\text { Group 3 }\end{array}$ \\
\hline Usability of the FMP & Sig. & $0,009^{* *}$ & 0,868 & $0,045^{*}$
\end{tabular}




\begin{tabular}{|c|c|c|c|c|}
\hline & $\begin{array}{c}\text { Mean difference } \\
(\mathrm{I}-\mathrm{J})\end{array}$ & 0,41637 & 0,06201 & $-0,35436$ \\
\hline \multirow{3}{*}{ 95\% Confidence Interval } & Std. Error & 0,14055 & 0,12208 & 0,14777 \\
\hline & Lower Bound & 0,08474 & $-0,2260$ & $-0,7030$ \\
\hline & Upper Bound & 0,74798 & 0,3500 & $-0,0057$ \\
\hline \multirow{3}{*}{$\begin{array}{c}\text { Decision support from } \\
\text { FMP }\end{array}$} & Sig. & $0,000 * * *$ & 0,872 & $0,000^{* * *}$ \\
\hline & $\begin{array}{c}\text { Mean difference } \\
(\mathrm{I}-\mathrm{J})\end{array}$ & 0,68461 & 0,06168 & $-0,62293$ \\
\hline & Std. Error & 0,14149 & 0,12386 & 0,14952 \\
\hline \multirow[t]{2}{*}{ 95\% Confidence Interval } & Lower Bound & 0,35084 & $-0,2305$ & $-0,9756$ \\
\hline & Upper Bound & 1,01837 & 0,3539 & $-0,2702$ \\
\hline \multirow{3}{*}{$\begin{array}{c}\text { Experience of } \\
\text { restrictiveness of advisory } \\
\text { services }\end{array}$} & Sig. & $0,03425^{*}$ & 0,726 & 0,193 \\
\hline & $\begin{array}{c}\text { Mean difference } \\
\text { (I-J) }\end{array}$ & 0,39570 & 0,10607 & $-0,28962$ \\
\hline & Std. Error & 0,15786 & 0,13891 & 0,16646 \\
\hline \multirow[t]{2}{*}{ 95\% Confidence Interval } & Lower Bound & 0,02336 & $-0,2216$ & $-0,6822$ \\
\hline & Upper Bound & 0,76803 & 0,4337 & 0,1030 \\
\hline
\end{tabular}

Table 9. Post hoc test Games-Howell on comparison of satisfaction with forest management plan (FMP) and advisory services with forest management style. Means are on a scale from 1 (not at all useful) to 5 (very useful). Statistically significant values of mean differences are marked with asterisks $(\mathrm{p}<0.05=* ; \mathrm{p}<0.01=* * ;$ and $\mathrm{p}<0.001=* * *)$.

\begin{tabular}{|c|c|c|c|c|}
\hline & & $\begin{array}{c}\text { Group 1 } \\
\text { Timber production } \\
\text { purpose }\end{array}$ & Group 1 & Group 2 \\
\hline & & $\begin{array}{c}\text { vs } \\
\text { Group } 2 \\
\begin{array}{c}\text { Nature management } \\
\text { purpose }\end{array}\end{array}$ & $\begin{array}{c}\text { vs } \\
\text { Group } 3 \\
\text { Diversifying forest } \\
\text { management }\end{array}$ & $\begin{array}{c}\text { vs } \\
\text { Group } 3\end{array}$ \\
\hline Usability of the FMP & Sig. & 0.063 & 0.307 & 0.331 \\
\hline & $\begin{array}{c}\text { Mean difference } \\
\text { (I-J) }\end{array}$ & 0.40909 & 0.17662 & -0.23247 \\
\hline & Std. Error & 0.17869 & 0.11996 & 0.16240 \\
\hline 95\% Confidence Interval & Lower Bound & -0.0175 & -0.1076 & -0.6226 \\
\hline & Upper Bound & 0.8357 & 0.4608 & 0.1577 \\
\hline Decision support from FMP & Sig. & $0.012^{* *}$ & 0.972 & $0.010^{* *}$ \\
\hline & $\begin{array}{c}\text { Mean difference } \\
(\mathrm{I}-\mathrm{J})\end{array}$ & 0.54825 & 0.02692 & -0.52133 \\
\hline & Std. Error & 0.18655 & 0.11957 & 0.17172 \\
\hline 95\% Confidence Interval & Lower Bound & 0.1028 & -0.2562 & -0.9337 \\
\hline & Upper Bound & 0.9937 & 0.3100 & -0.1089 \\
\hline Experience of restrictiveness & Sig. & 0.097 & $0.007 * *$ & 0.998 \\
\hline & $\begin{array}{c}\text { Mean difference } \\
(\mathrm{I}-\mathrm{J})\end{array}$ & -0.400 & -0.388 & 0.012 \\
\hline & Std. Error & 0.191 & 0.127 & 0.187 \\
\hline 95\% Confidence Interval & Lower Bound & -0.86 & -0.69 & -0.44 \\
\hline & Upper Bound & 0.06 & -0.09 & 0.46 \\
\hline
\end{tabular}

